\title{
Peringkat Pemikiran Imam al-Ash'ari dalam Akidah
}

\author{
Stages of Imam al-Ash'ari Thought in Theology
}

\author{
MUHAMMAD RASHIDI WAHAB* \& SYED HADZRULLATHFI SYED OMAR ${ }^{1}$
}

\begin{abstract}
Imam al-Ash'ari was the founder and leading figure of the Asha'irah sect of the Ahl al-Sunnah wa al-Jama'ah. His approach is often used as a main reference by Muslims since the time of its appearance until now concerning questions of faith. Some other schools of thought try to claim that the holding of Imam al-Ash'ari doctrine coincides with their beliefs. Imam al-Ash'ari is said to go through three stages of thought before he returned to the Ahl al-Sunnah wa al-Jama'ah at the end of his life to follow Imam Ahmad bin Hanbal the leadership of Salaf. Therefore, anyone who does not abide by the final stand of Imam al-Ash'ari, they are not considered as Asha'irah followers for conflicting Imam al-Ash'ari and Salaf scholars as recognized the best of generations. To assure the issues, this article is put forward to reexamine of the truth of the allegations either Imam al-Ash'ari has gone through three stages of thought or otherwise. Through document analysis method based on the works of Imam al-Ash'ari and his followers, the study found that Imam al-Ash'ari only used two stages of thought; Mu'tazilah initially and Ahl al-Sunnah wa al-Jama'ah in the end. Imam al-Ash'ari also used the tafwid Salafand Khalaf interpretation methods especially in interacting with mutashabihat texts throughout his stay with the Ahl al-Sunnah wa al-Jama'ah. The study also identified that the disagreements among Asha'irah when determining the thoughts of Imam al-Ash'ari is due to their uncertainty about the exact date of his works written.
\end{abstract}

\section{Keywords: Ahl al-Sunnah wa al-Jama'ah, al-Ash'ari, Asha'irah, khalaf, salaf}

Imam al-Ash'ari merupakan pengasas aliran pemikiran akidah Asha'irah yang menjadi salah satu tunjang utama bagi mazhab Ahl al-Sunnah wa al-Jama'ah (Al-Zabidi 1989: 2/8). Kajian The Royal Islamic Strategic Studies Centre (2010: 17) menunjukkan bahawa Asha'irah dan Maturidiyyah merupakan aliran majoriti umat Islam dengan 90 peratus daripada keseluruhan umat Islam adalah pengikut aliran Ahl al-Kalam ini. Hasil kajian ini turut dipersetujui oleh alQaradawi iaitu ketika mempertahankan Universiti al-Azhar yang berpegang dengan akidah Asha'irah daripada tohmahan Salafiyyah Wahabiyyah, beliau menjelaskan bahawa Asha'irah merupakan pegangan majoriti umat Islam di seluruh dunia semenjak dahulu sehingga kini (www.qaradawi.net). Begitu juga di Malaysia dan rantau Nusantara, tidak keterlaluan jika dikatakan bahawa majoriti masyarakat Islam khususnya masyarakat awam dalam aspek akidah dan kepercayaan berfahaman aliran Asha'irah (Abdul Shukor 1998: 13).

Memandangkan Imam al-Ash'ari adalah tokoh terpenting dalam kelangsungan Ahl alSunnah wa al-Jama'ah, maka sebarang pendekatan yang dikemukakan oleh beliau dalam sesuatu persoalan akidah sentiasa mendapat perhatian serius daripada umat Islam. Maka pelbagai individu mewakili aliran pemikiran masing-masing, selain Asha'irah sendiri, turut berusaha mengaitkan doktrin aliran mereka mempunyai persamaan dengan pendirian Imam al-

\footnotetext{
${ }^{1}$ Muhammad Rashidi Wahab*(Corresponding author), Department of Usuluddin, Faculty of Islamic Contemporary Studies, Universiti Sultan Zainal Abidin, 21300 KUALA TERENGGANU, Terengganu, Malaysia. Email: muhdrashidi85@gmail.com; Syed Hadzrullathfi Syed Omar, Ph.D., Lecturer at Department of Usuluddin, Faculty of Islamic Contemporary Studies, Universiti Sultan Zainal Abidin, 21300 KUALA TERENGGANU, Terengganu, Malaysia. Email: sylutfi@unisza.edu.my.
} 
Ash'ari. Namun artikel ini hanya menfokuskan kepada satu dakwaan sahaja yang ditimbulkan oleh golongan Salafiyyah Wahabiyyah, iaitu Imam al-Ash'ari dikatakan melalui tiga peringkat pemikiran sebelum kembali kepada Ahl al-Sunnah wa al-Jama'ah. Justeru, setelah Imam alAsh'ari meninggalkan Muktazilah (peringkat pertama), beliau didakwa menjadi pengikut Ibn Kullab sebelum beliau bertaubat (peringkat kedua) dan pengakhirannya kembali kepada Salaf dan Ahl al-Sunnah wa al-Jama'ah (peringkat ketiga). Mereka turut menimbulkan polemik dengan menyatakan bahawa pegangan kebanyakan pengikut Asha'irah kini tidak bertepatan dengan Imam al-Ash'ari, malah ia berasaskan metodologi Ibn Kullab semata-mata, terutamanya berkaitan takwilan nas-nas sifat mutashabihat (al-Mahmud 1995: 337-339). Tuduhan ini menimbulkan suasana tidak tenteram dalam kalangan umat Islam kerana dimaklumi mereka telah menjadi sebahagian daripada pengikut Asha'irah semenjak sekian lama dengan metodologi yang masyhur diterima pakai dalam akidah Ahl al-Sunnah wa al-Jama'ah.

Bagi merungkaikan pertikaian tersebut, atau dengan perkataan lain sejauh manakah kebenaran Imam al-Ash'ari dikatakan melalui tiga peringkat pemikiran, ia menjadi fokus utama artikel ini diketengahkan, memandangkan kurangnya perhatian penulis kontemporari tentang isu tersebut. Menerusi kaedah analisis kandungan dokumen daripada pelbagai sumber primer dan skunder berautoriti, khususnya karya-karya Imam al-Ash'ari dan ulama muktabar Asha'irah sendiri, artikel ini cuba mengetengahkan suatu analisis tentang isu berkaitan untuk mengenal pasti peringkat pemikiran Imam al-Ash'ari, iaitu sama ada beliau beliau benar-benar melalui tiga peringkat pemikiran sebagaimana dakwaan atau sebaliknya. Selain itu, artikel turut menjelaskan tentang metodologi pendalilan Imam al-Ash'ari dalam akidah berdasarkan penelitian penulis terhadap beberapa kenyataan beliau ketika mempertahankan Ahl al-Sunnah wa al-Jama'ah. Sebagai permulaan, artikel ini akan memperkenalkan Imam al-Ash'ari secara ringkas sahaja memandangkan biodata lengkap beliau sering dibincangkan dalam pelbagai tulisan lain.

\section{Sekitar Kemunculan Imam al-Ash'ari}

Ahl al-Sunnah wa al-Jama'ah dapat dirumuskan sebagai golongan terbesar atau al-jama'ah umat Islam yang mengikut serta mendokong al-Quran serta sunnah Rasulullah s.a.w. sama ada dari aspek akidah, fikah dan tasawuf (al-Mahdali t.th: 7). Kemunculan Ahl al-Sunnah wa al-Jama'ah jauh berbeza dengan keadaan beberapa aliran pemikiran lain seperti aliran Shi'ah dan Khawarij kerana kemunculan awal kedua-dua golongan ini bermotifkan politik kepimpinan umat Islam. Disebabkan hal tersebut menjadikan Shi'ah dan Khawarij sebagai dua buah parti politik agama terawal lahir dalam sejarah umat Islam, sebelum kedua-dua aliran ini berkembang menjadi sebahagian daripada aliran pemikiran akidah (Abdul Shukor 1998: 14; Abu Zahrah 1996: 31). Walaupun tarikh sebenar kemunculan istilah Ahl al-Sunnah wa al-Jama'ah tidak diketahui secara tepat, namun penamaan $\mathrm{Ahl}$ al-Sunnah wa al-Jama'ah telah digunakan semenjak generasi Salaf lagi. Sebagai contoh, ketika menafsirkan ayat 106 dari surah ali-'Imran, Ibn 'Abbas r.a. (m. $68 \mathrm{H}$ ) menyatakan bahawa muka orang-orang yang menjadi putih berseri itu ialah golongan Ahl al-Sunnah wa al-Jama'ah, manakala muka orang-orang yang menjadi hitam legam ialah ahli-ahli bidaah yang sesat serta pengikut-pengikut mereka (Ibn Kathir 1999: 92). Ibn Sirin (m. 110H) pula menggunakan istilah Ahl al-Sunnah wa al-Jama'ah ketika menyatakan bahawa periwayatan hadis daripada Ahl al-Sunnah wa al-Jama'ah sahaja diterima, sedangkan periwayatan daripada ahli-ahli bidaah tidak diterima (Muslim 2008: 9).

Pada kurun kedua dan ketiga Hijrah, umat Islam daripada kalangan Ahl al-Sunnah wa alJama'ah dilanda dengan ancaman pemikiran akidah serta ditentang hebat oleh aliran bidaah seperti Muktazilah, Shi'ah, Khawarij dan sebagainya lagi. Tokoh-tokoh aliran bidaah dilantik menjadi pemimpin dalam masyarakat menyebabkan ketulenan ajaran Islam sedikit demi sedikit semakin terhakis (Ibn al-'Asakir 1347H: 164). Muktazilah merupakan aliran bidaah yang mendapat dokongan kuat pemerintah ketika itu terutamanya semasa zaman pemerintahan alMa'mun, al-Mu'tasim dan al-Wathiq. Mereka memaksa masyarakat mengakui pegangan Muktazilah tentang kemakhlukan al-Quran sehingga pemikiran aliran Muktazilah berjaya 
dikembangkan ke serata tempat terutamanya di Baghdad. Imam Ahmad bin Hanbal (m. $241 \mathrm{H})$ di antara ulama Ahl al-Sunnah wa al-Jama'ah yang tegas dalam mempertahankan akidah Ahl alSunnah wa al-Jama'ah dengan menyatakan bahawa al-Quran adalah Kalam Allah s.w.t. bukan makhluk (al-'Amraji 2000: 164).

Kemunculan aliran Asha'irah yang dipimpin oleh Imam Abu al-Hasan al-Ash'ari bermula pada akhir kurun ketiga Hijrah ketika Mu'tazilah masih berkuasa. Nama penuh beliau ialah 'Ali bin Isma'il bin Ishaq bin Salim bin Isma'il bin 'Abd Allah bin Musa bin Bilal bin Abi Burdah bin Abi Musa al-Ash'ari (Ibn al-'Asakir 1347H: 34). Beliau dilahirkan pada tahun $260 \mathrm{Hijrah} \mathrm{di}$ Basrah dan meninggal dunia pada tahun 330 Hijrah di Baghdad (Ibn al-'Asakir 1347H: 146-147; Abu Zahrah 1996: 163). Sebahagian pendapat menyatakan Imam al-Ash'ari meninggal dunia pada 320 Hijrah atau 324 Hijrah (al-Asnawi 1987: 1/47; Ibn al-'Asakir 1347H: 147). Imam alAsh'ari dilaporkan bertaubat daripada berpegang dengan fahaman Muktazilah untuk kembali kepada Ahl al-Sunnah wa al-Jama'ah sehinggalah aliran Asha'irah menjadi golongan majoriti dalam mempertahankan akidah Islam daripada aliran-aliran bidaah (Ibn al-'Asakir 1347H: 39).

Menurut Ahmad Mahmud Subhi (1985: 2/46-2/47), peristiwa terpenting menyebabkan Imam al-Ash'ari bertindak keluar daripada aliran Muktazilah untuk bersama dengan Ahl alSunnah wa al-Jama'ah ialah, berlaku perselisihan pendapat dengan gurunya al-Jubba'i mengenai perbuatan Allah s.w.t. berdasarkan konsep al-salah wa al-aslah. Pada perdebatan tersebut, alJubba'i tidak mampu mempertahankan akidah Muktazilah daripada pertanyaan Imam al-Ash'ari sehingga menimbulkan perasaan ragu-ragu dalam pemikiran Imam al-Ash'ari mengenai kebenaran fahaman Muktazilah tersebut (Ibn al-'Asakir 1347H: 39). Walaupun begitu, menurut Ibn al-'Asakir, terdapat dua faktor atau sebab lain yang turut mendorong Imam al-Ash'ari bertindak keluar daripada Muktazilah dan menyertai Ahl al-Sunnah wa al-Jama'ah iaitu: Pertamanya, keraguan Imam al-Ash'ari terhadap pegangan Muktazilah yang terlalu melebihkan dan mendahulukan akal berbanding al-Quran dan sunnah Rasulullah s.a.w. Hasil daripada keraguan dan kecelaruan pemikiran ini yang menyebabkan berlakunya perdebatan Imam alAsh'ari dengan gurunya al-Jubba'i. Kedua, pada bulan Ramadan, Imam al-Ash'ari telah bermimpi bertemu dengan Rasulullah s.a.w. Dalam mimpi tersebut, Rasulullah s.a.w. meminta Imam alAsh'ari membela al-Quran dan sunnah Baginda daripada dipermain-mainkan oleh aliran bidaah terutamanya Muktazilah (Ibn al-'Asakir 1347H: 38-40).

Setelah meninggalkan Muktazilah, Imam al-Ash'ari mempergiatkan aktiviti penyampaian dakwah akidah Ahl al-Sunnah wa al-Jama'ah yang sebenar dengan mengajar di masjid-masjid dan menghadiri majlis-majlis perdebatan. Imam al-Ash'ari menghadiri majlismajlis Muktazilah untuk berdebat dengan mereka sehinggkan ada sebilangan orang bertanya kepada beliau tentang tujuan beliau masih lagi bergaul dengan ahli bidaah seperti Muktazilah. Imam al-Ash'ari menjawab bahawa kebanyakan tokoh penting Muktazilah memegang jawatan tinggi dalam kerajaan, maka adalah mustahil untuk mereka datang kepada beliau untuk berbincang. Jika beliau tidak pergi kepada mereka, ini bermakna mereka tidak mengetahui tentang kebenaran Ahl al-Sunnah wa al-Jama'ah (Ibn al-'Asakir 1347H: 68-69).

Sebagai tokoh besar dalam Ahl al-Sunnah wa al-Jama'ah, Imam al-Ash'ari telah meninggalkan hasil penulisannya yang banyak iaitu sekitar 300 buah karya sepanjang beliau bersama dengan Ahl al-Sunnah wa al-Jama'ah (Ibn al-'Asakir 1347H: 127). Namun hanya beberapa buah karya sahaja masyhur sampai kepada umat Islam hari ini antaranya; al-Ibanah 'an Usul al-Diyanah, al-Luma' fi al-Rad 'ala Ahl al-Zaygh wa al-Bid'a, Maqalat al-Islamiyyin wa Ikhtilaf al-Musallin, Risalah fi al-Istihsan al-Khawd fi 'Ilm al-Kalam dan Risalah Ila Ahl al-Thaghr.

Selain itu, Imam al-Ash'ari turut meninggalkan murid-muridnya yang ramai dalam meneruskan penyebaran aliran Asha'irah antaranya, Abu 'Abd Allah bin Mujahid, Abu al-Hasan al-Bahili, Abu al-Hussin Bundar bin al-Hussin al-Shayrazi, Abu Muhammad al-Tabari, Abu Bakar al-Qaffal, Abu Sahal al-Sa'luki, Abu Zayd al-Marwazi, Abu 'Abd Allah bin Khafif al-Shayrazi, Abu Bakar al-Jurjani, Abu al-Hasan 'Abd al-'Aziz bin Muhammad bin Ishaq, Abu al-Hasan 'Ali bin Muhammad bin Mahdi dan lain-lain lagi (Ibn al-'Asakir 1347H: 177-195). Manakala gelaran nama al-Ash'ari pula merupakan nisbah daripada keturunan salah seorang sahabat Rasulullah s.a.w. iaitu Abu Musa al-Ash'ari r.a. yang merupakan datuk kepada Imam al-Ash'ari. Rasulullah 
s.a.w. pernah menyatakan bahawa kaum yang mengikut Abu Musa al-Ash'ari r.a. adalah kaum yang selamat dan dicintai oleh Allah s.w.t. Ia dilihat sebagai salah satu petanda bahawa pegangan aliran Asha'irah adalah bertepatan dengan petunjuk al-Quran dan hadis kerana Imam al-Ash'ari dilaporkan berpegang dengan pegangan yang sama dengan akidah datuknya setelah beliau kembali kepada Ahl al-Sunnah wa al-Jama'ah (al-Sharastani 1993: 1/106):

'Iyad al-Ash'ari berkata: Ketika turunnya ayat (bermaksud: Allah akan mendatangkan satu kaum yang Allah mencintai mereka dan mereka mencintai-Nya (al-Ma'idah (5): 54)) maka sabda Rasulullah s.a.w.: Mereka adalah kaum kamu wahai Aba Musa. Sambil itu Rasulullah s.a.w. menunjukkan tangannya kepada Abi Musa al-Ash'ari (al-Hakim (3220) 1990: 2/342).

Ketika menafsir ayat (al-Ma'idah, 5: 54) dan menjelaskan pengertian hadis di atas, alQushairi menyatakan bahawa yang dimaksudkan dengan hadis itu adalah pengikut Imam alAsh'ari yang termasuk dalam kaum Abu Musa al-Ash'ari. Menurut al-Qushairi lagi, penisbahan ini adalah bertepatan dengan al-Quran kerana setiap penisbahan kaum yang didatangkan oleh al-Quran terhadap para rasul-Nya, maka yang dimaksudkan dengan penisbahan itu adalah pengikut para rasul tersebut (al-Qurtubi 2006: 8/52-8/53). Oleh itu, menisbahkan Imam alAsh'ari dan pengikut alirannya kepada kaum Abu Musa al-Ash'ari sepertimana yang dinyatakan oleh hadis mempunyai sandaran yang kukuh. Hal ini menjadikan aliran Asha'irah terus bertahan dan berkembang sehingga sampai kepada generasi hari ini.

\section{Peringkat Pemikiran Imam al-Ash'ari}

Memandangkan Imam al-Ash'ari merupakan salah seorang tokoh besar Ahl al-Sunnah wa alJama'ah, maka pelbagai pihak berusaha untuk menyatakan pegangan aliran mereka mempunyai persamaan dengan pegangan Imam al-Ash'ari. Antaranya Ibn Taymiyyah (m. $728 \mathrm{H})$ telah menyatakan bahawa Imam al-Ash'ari telah melalui tiga peringkat dalam kematangan pemikiran beliau, iaitu: Peringkat pertama: Imam al-Ash'ari berada dalam Muktazilah sehingga beliau berusia 40 tahun; Peringkat kedua: Imam al-Ash'ari keluar daripada Muktazilah untuk mengikut pegangan Ibn Kullab (m. 240H); dan Peringkat ketiga: Imam al-Ash'ari keluar daripada mengikut pegangan Ibn Kullab untuk kembali kepada Ahl al-Sunnah wa al-Jama'ah dengan mengarang karyanya al-Ibanah 'an Usul al-Diyanah. Oleh itu, Ibn Taymiyyah dan pendokongnya mendakwa bahawa para pengikut Asha'irah sekarang merupakan pengikut Ibn Kullab dan bukan pengikut sebenar Imam al-Ash'ari dan Ahl al-Sunnah wa al-Jama'ah. Bagi mereka, pegangan Imam al-Ash'ari pada peringkat ketiga adalah sama dengan pegangan kumpulan mereka yang dikatakan mengikut metod Imam Ahmad bin Hanbal terutamanya dalam tidak melakukan takwilan terhadap nas-nas sifat mutashabihat (al-Mahmud 1995: 337-339). Melihat kepada dakwaan ini, penulis mendapati terdapat beberapa persoalan yang perlu dijelaskan, antaranya:

\section{Benarkah Imam al-Ash'ari melalui tiga peringkat pemikiran?}

Kisah Imam al-Ash'ari melalui tiga peringkat pemikiran tidak pernah disebutkan oleh manamana tokoh ulama silam selepas Imam al-Ash'ari. Tokoh-tokoh tersebut mustahil bersepakat atau sengaja melupakan kisah ini jika benar Imam al-Ash'ari telah melalui tiga peringkat pemikiran memandangkan beliau merupakan seorang ulama yang sangat masyhur untuk dijadikan tempat rujukan (Hamda al-Sinan \& Fauzi al-Anjari 2006: 45). Adapun riwayat yang sampai kepada umat Islam hari ini adalah seperti tulisan Ibn al-'Asakir yang dinukilkan daripada Abu Bakar Ibn Furak bahawa Imam al-Ash'ari hanya melalui dua peringkat pemikiran sahaja iaitu Mu'tazilah dan Ahl al-Sunnah wa al-Jama'ah (Ibn al-'Asakir 1347H: 127). Kenyataan sama turut dikemukakan oleh Ibn Khalikan (t.th: 3/284-3/285) dengan menegaskan bahawa Imam al-Ash'ari merupakan seorang pembela Ahl al-Sunnah wa al-Jama'ah. Menurut Ibn Khaldun (t.th: 3/1088) pula, setelah Imam al-Ash'ari berpaling daripada Muktazilah, beliau 
telah mengikut tokoh-tokoh salaf daripada kalangan Ahl al-Sunnah wa al-Jama'ah seperti Ibn Kullab, al-Muhasibi dan al-Qalanisi. Walau bagaimanapun, sebilangan ulama Asha'irah seperti al-Zabidi (1989: 2/4-2/8) menyatakan bahawa Imam al-Ash'ari telah melalui tiga peringkat pemikiran terutamanya berkaitan nas-nas sifat mutashabihat iaitu: peringkat pertama, bersama Mu'tazilah dalam menafikan sifat khabariyyah; peringkat kedua, berpegang dengan metod takwil Khalaf, dan; peringkat ketiga, berpegang dengan metod tafwid Salaf (al-Ansari T.th: 76). Harus difahami bahawa penjelasan al-Zabidi ini bukan menunjukkan Imam al-Ash'ari melalui tiga peringkat pemikiran sebelum kembali kepada Ahl al-Sunnah wa al-Jama'ah sebagaimana dakwaan Ibn Taymiyyah. Sebaliknya kenyataan tersebut tetap menunjukkan Imam al-Ash'ari hanya melalui dua peringkat pemikiran sahaja, cumanya ketika Imam al-Ash'ari bersama Ahl alSunnah wa al-Jama'ah, menurut al-Zabidi, beliau dikatakan berpegang kepada takwil Khalaf pada awalnya dan tafwid Salaf pada akhirnya. Pandangan ini timbul disebabkan perselisihan ulama dalam menentukan karya terawal dan terakhir Imam al-Ash'ari, iaitu sama ada karya terawal dan terakhir beliau menggunakan metod Salaf atau Khalaf. Selain itu, pendapat yang menyatakan bahawa Imam al-Ash'ari meninggalkan Muktazilah ketika beliau berumur 40 tahun, perlu diteliti kembali kerana jika dirujuk kepada tarikh surat Imam al-Ash'ari kepada Ahl al-Thaghr (berdasarkan karya Risalah Ila Ahl al-Thaghr) iaitu pada tahun 297H, menunjukkan Imam al-Ash'ari pada ketika itu berumur 37 setelah dibandingkan dengan tahun kelahiran beliau $260 \mathrm{H}$. Ini bermaksud Imam al-Ash'ari telah meninggalkan Muktazilah sebelum atau sekurang-kurangnya berumur 37 tahun lagi memandangkan karya tersebut bukan karya terawal beliau setelah meninggalkan Muktazilah (al-Ash'ari 2002: 105; 131).

\section{Adakah Ibn Kullab ulama Ahl al-Sunnah wa al-Jama'ah?}

Selain daripada kenyataan Ibn Khaldun (t.th: 3/1088) di atas tentang Ibn Kullab merupakan salah seorang ulama Ahl al-Sunnah wa al-Jama'ah generasi Salaf, Ibn al-'Asakir turut menukilkan kata-kata al-Qayrawani yang menolak pandangan Muktazilah kerana menyatakan Ibn Kullab adalah ahli bidaah. Bahkan beliau menyatakan bahawa Ibn Kullab merupakan salah seorang ulama Ahl al-Sunnah wa al-Jama'ah yang berusaha keras menentang aliran bidaah (Ibn al-'Asakir 1347H: 406). Al-Dhahabi dan al-Subki juga menyatakan perkara yang sama terhadap Ibn Kullab dan mengakui bahawa beliau merupakan seorang tokoh ulama Ahl al-Sunnah wa alJama'ah generasi Salaf (al-Dhahabi 1996: 11/174; al-Subki t.th: 2/300). Disebabkan itu, alBukhari dalam kebanyakan perkara berkaitan dengan persoalan akidah dikatakan akan mengambil pendapat Ibn Kullab dan al-Karabisi (al-'Asqalani 2001: 1/293).

Manakala dakwaan sebilangan pengikut Imam Ahmad bin Hanbal bahawa Ibn Kullab telah menyimpang daripada Ahl al-Sunnah wa al-Jama'ah adalah disebabkan perselisihan yang berlaku di antara beliau dengan Imam Ahmad bin Hanbal berkenaan bacaan al-Quran seseorang manusia itu dianggap sebagai makhluk atau tidak. Ibn Kullab serta ulama lain seperti alKarabisi, al-Muhasibi, al-Qalanisi, al-Bukhari, Muslim dan lain-lain menyatakan bahawa bacaan itu adalah makhluk, sedangkan Imam Ahmad bin Hanbal tetap menegaskan bacaan itu bukan makhluk. Disebabkan perselisihan ini, sebilangan pengikut Imam Ahmad bin Hanbal mendakwa bahawa Ibn Kullab adalah ahli bidaah Muktazilah. Hakikatnya, kebenaran dalam persoalan ini lebih memihak kepada Ibn Kullab dan para ulama lain, namun tindakan Imam Ahmad bin Hanbal dilihat sebagai langkah pencegahan awal terhadap isu kemakhlukkan al-Quran yang menjadi persoalan hangat pada ketika itu (al-Dhahabi 1996: 11/175; Hamda al-Sinan \& Fauzi alAnjari 2006: 51-54).

\section{Benarkah karya terakhir Imam al-Ash'ari ialah al-Ibanah 'an Usul al-Diyanah mengikut metod Ahl al-Sunnah wa al-Jama'ah dengan meninggalkan metod Ibn Kullab}

Perlu ditegaskan bahawa kandungan al-Ibanah 'an Usul al-Diyanah adalah mengikut pegangan Imam Ahmad bin Hanbal dan juga Ibn Kullab sebagaimana dilaporkan oleh Ibn Hajar al'Asqalani (al-Ash'ari 1977: 2/20; al-'Asqalani (4256) 2002: 4/487). Malah tindakan Imam 
Ahmad bin Hanbal mentakwilkan beberapa nas sifat mutashabihat seperti lafaz ja'a (datang Tuhan) ditakwilkan sebagai datangnya pahala dari Tuhan, menunjukkan metod takwil bukan sesuatu yang baru dikenali pada zaman Khalaf (Ibn Kathir 1998: 14/386). Jika Imam al-Ash'ari mempraktikkan kedua-dua metod tersebut sama ada tafwid atau takwil, ia masih lagi bertepatan dengan pendirian ulama Salaf seperti Imam Ahmad bin Hanbal. Manakala mengenai karya terawal dan terakhir Imam al-Ash'ari, berlaku perselisihan pendapat dalam menentukan sama ada al-Ibanah 'an Usul al-Diyanah atau al-Luma' fi al-Rad 'ala Ahl al-Zaygh wa al-Bid'a. Menurut al-Kawthari (2009: 62), penulisan Imam al-Ash'ari paling awal setelah beliau keluar daripada Muktazilah ialah al-Ibanah 'an Usul al-Diyanah, sedangkan al-Luma' fi al-Rad 'ala Ahl al-Zaygh wa al-Bid'a ditulis selepas menghasilkan al-Ibanah 'an Usul al-Diyanah tanpa beliau menentukan sama ada karya tersebut adalah karya terakhir Imam al-Ash'ari atau sebaliknya. Menurut al-Kawthari lagi, selain bagi menjelaskan pegangan yang menjadi ikutan beliau, tujuan Imam al-Ash'ari menulis al-Ibanah 'an Usul al-Diyanah ialah untuk memberi kesedaran kepada sebahagian pengikut Imam Ahmad bin Hanbal seperti al-Barbahari yang telah terjerumus sebagai mujassimah atau mushabbihah. Kemudiannya mereka ini telah mengubah dan memalsukan isi kandungan al-Ibanah 'an Usul al-Diyanah agar ianya sesuai dengan pegangan kumpulan mereka sehingga sampai ke generasi hari ini.

Penjelasan al-Kawthari ini disokong dengan kisah yang dibawakan oleh al-Dhahabi tentang penolakan al-Barbahari terhadap al-Ibanah 'an Usul al-Diyanah setelah karyanya itu dikemukakan oleh Imam al-Ash'ari kepadanya (al-Dhahabi 1996: 12/82). Disebabkan hal tersebut, kebanyakan ulama Asha'irah kontemporari meragui kesahihan kandungan al-Ibanah 'an Usul al-Diyanah yang sampai kepada umat Islam kini. Mereka turut berpendapat bahawa kandungan al-Ibanah 'an Usul al-Diyanah mungkin telah diubah mengikut kesesuaian pentahqiq kerana terdapat perbezaan kandungan di antara beberapa cetakan. Namun mereka beranggapan bahawa al-Ibanah 'an Usul al-Diyanah yang ditahqiq oleh Fawqiyah Husin Mahmud adalah cetakan terbaik untuk dijadikan rujukan kerana ketelitian pentahqiq dalam mengkaji beberapa manuskrip karya itu (Hamda al-Sinan \& Fauzi al-Anjari 2006: 62). Bahkan terdapat sebilangan pengikut Asha'irah meragui al-Ibanah 'an Usul al-Diyanah adalah karya Imam alAsh'ari kerana beberapa faktor antaranya; sebahagian riwayat daripada Ibn al-'Asakir tidak mempunyai sanad, beberapa kandungan bersalahan dengan ulama Asha'irah, sesetengah dakwaan Imam al-Ash'ari terhadap Muktazilah tidak dijumpai dalam karya Muktazilah sendiri dan al-Baqillani turut mempunyai karya bertajuk al-Ibanah dengan al-Ibanah yang dinisbahkan kepada Imam al-Ash'ari mempunyai gaya bahasa hampir sama dengan karya-karya al-Baqillani lain (al-Ghari 2001: 53-59). Namun dakwaan ini tertolak kerana kebanyakan ulama Asha'irah silam antaranya Ibn al-'Asakir, al-Bayhaqi, al-Dhahabi, Ibn Kathir, al-Zabidi dan lain-lain menyakini bahawa al-Ibanah 'an Usul al-Diyanah adalah karya Imam al-Ash'ari (al-Ansari T.th: 77-87), cumanya mereka tidak bersepakat tentang kesahihan kandungannya sahaja.

Selain itu, kenyataan al-Kawthari bahawa al-Ibanah 'an Usul al-Diyanah adalah kitab terawal Imam al-Ash'ari turut dipersetujui oleh Hamudah Gharabah (pentahqiq al-Luma' fi alRad 'ala Ahl al-Zaygh wa al-Bid'a). Beliau menyatakan tindak balas serta gaya penulisan Imam al-Ash'ari dalam al-Ibanah 'an Usul al-Diyanah jelas menunjukan beliau baru sahaja meninggalkan Mu'tazilah. Malah menurut pemerhatian beliau, al-Luma' fi al-Rad 'ala Ahl alZaygh wa al-Bid'a adalah karya terakhir Imam al-Ash'ari kerana penulisannya itu memperlihatkan keilmuan dan kematangan beliau dalam membentuk kerangka pemikirannya yang tersendiri dengan menggabungkan dalil naqli dan dalil 'aqli (Hamudah Gharabah 1955: 7). Manakala Fawqiyah Husin Mahmud (pentahqiq al-Ibanah 'an Usul al-Diyanah) telah menyusun karya-karya Imam al-Ash'ari mengikut turutan tahun penulisan beliau berdasarkan beberapa riwayat sepertimana berikut: 1. Al-Ibanah 'an Usul al-Diyanah (antara 300H-320H). 2. Al-Luma' fi al-Rad 'ala Ahl al-Zaygh wa al-Bid'a (sebelum 320H). 3. Maqalat al-Islamiyyin wa Ikhtilaf alMusallin (sebelum 320H). 4. Risalah Ila Ahl al-Thaghr (selepas 320H) (Fawqiyah Husin Mahmud 1977: 1/91).

Berdasarkan penelitian di atas, dakwaan Ibn Taymiyyah bahawa Imam al-Ash'ari melalui tiga peringkat pemikiran sebelum kembali menjadi Ahl al-Sunnah wa al-Jama'ah 
didapati sebagai kurang bertepatan dengan fakta diperolehi. Hakikatnya, Imam al-Ash'ari hanya melalui dua peringkat pemikiran sahaja, iaitu mengikut Muktazilah dan kemudian bersama Ahl al-Sunnah wa al-Jama'ah selepas beliau meninggalkan Muktazilah, pegangan ini kekal sehingga beliau wafat. Selain itu, Imam al-Ash'ari turut menjadikan Imam Ahmad bin Hanbal dan Ibn Kullab sebagai rujukan dalam mempertahankan akidah Ahl al-Sunnah wa al-Jama'ah daripada ancaman ahli bidaah sama ada dalam penulisan atau dakwah beliau selepas keluar daripada aliran Muktazilah. Manakala keseluruhan pendapat Imam al-Ash'ari bukan sahaja harus dirujuk kepada karya-karyanya yang masih lagi menjadi bahan perdebatan, bahkan ia juga perlu dirujuk kepada karya-karya muridnya dan para pengikutnya yang muktabar.

\section{Metodologi Pendalilan Imam al-Ash'ari dalam Akidah}

Perbincangan mengenai metodologi pendalilan Imam al-Ash'ari dalam akidah pada artikel ini hanya menfokuskan kepada beberapa karya beliau yang masyhur sampai kepada umat Islam. Topik ini dilihat penting kerana ia berkaitan dengan permasalahan kajian bagi menentukan peringkat pemikiran Imam al-Ash'ari berpandukan tulisan-tulisan beliau tersebut. Justeru, ungkapan Imam al-Ash'ari dalam karyanya terutamanya setelah beliau mengisytiharkan diri keluar daripada Muktazilah akan dianalisis dan dijadikan ukuran untuk menentukan metodologi pendalilan Imam al-Ash'ari dalam akidah (Abdul Shukor 1994: 38).

Hal tersebut dijelaskan sebagaimana berikut: Pertama, dalil naqli. Imam al-Ash'ari mengemukakan pendirian beliau tentang dalil naqli dalam karyanya al-Ibanah 'an Usul alDiyanah dengan menyatakan bahawa pendirian beliau dalam persoalan akidah merupakan pandangan agama Islam yang berlandaskan al-Quran dan sunnah Rasulullah s.a.w. serta apa-apa yang diriwayatkan oleh para sahabat, tabi'in dan imam-imam hadis. Imam al-Ash'ari turut menjadikan Imam Ahmad bin Hanbal sebagai contoh ikutan dalam berhadapan dengan aliran pemikiran bidaah seperti Muktazilah, Qadariyyah, Jabariyyah, Shi'ah dan lain-lain (al-Ash'ari 1977: 2/20). Kedua, dalil 'aqli. Imam al-Ash'ari mengemukakan pendirian beliau tentang dalil 'aqli dalam karyanya Risalah fi al-Istihsan al-Khawd fi 'Ilm al-Kalam dengan menyatakan bahawa terdapat segolongan manusia menjadikan kejahilan sebagai asas pemikiran sehingga mereka tidak berusaha untuk berfikir dan menganalisis persoalan agama. Mereka lebih cenderung kepada bertaklid lantas mengkritik sesiapa sahaja yang menggunakan pemikiran untuk berinteraksi dengan agama dan menganggap perbuatan itu adalah menyeleweng. Imam alAsh'ari turut menjelaskan bahawa masalah agama hendaklah dikembalikan kepada dasar-dasar agama iaitu wahyu, manakala masalah akal dan deria hendaklah dikembalikan kepada sumber asalnya (al-Ash'ari 1995: 47-48).

Gabungan kedua-dua kenyataan di atas menunjukkan bahawa Imam al-Ash'ari telah meletakkan dalil naqli sebagai asas paling utama dalam pembinaan akidah Islam, manakala dalil 'aqli sebagai penyokong dan pelengkap kepada dalil naqli. Pada ungkapan pertama, Imam alAsh'ari didapati sangat menekankan pendekatan Salaf sehingga tidak memberikan kebebasan kepada akal, sebagaimana pegangan Imam Ahmad bin Hanbal. Imam al-Ash'ari menetapkan apa-apa yang didatangkan oleh al-Quran dan hadis berkenaan sifat-sifat Allah s.w.t., para rasulNya, hari akhirat, malaikat dan lain-lain tanpa sebarang pertikaian (Abu Zahrah 1996: 166; alZuhaili 2009: 1/105). Hal ini dibuktikan dengan kecenderungan Imam al-Ash'ari menggunakan metod tafwid (menetapkan) Salaf pada sifat-sifat Allah s.w.t., iaitu tidak menerima metod takwil ketika berinteraksi dengan nas-nas sifat mutashabihat melalui karya beliau al-Ibanah 'an Usul al-Diyanah dan Maqalat al-Islamiyyin wa Ikhtilaf al-Musallin (al-Ash'ari 1977: 2/21; 1990: 1/345-1/350). Contohnya, Imam al-Ash'ari telah menjelaskan tentang perihal istiwa sepertimana berikut:

Sesungguhnya Allah Taala beristiwa di atas Arasy sebagaimana yang difirmankan dan dengan makna yang dikehendaki-Nya. Istiwa itu Maha Suci daripada bersentuh, menetap, mengambil tempat, menjelma dan berpindah. Dia tidak menanggung Arasy, bahkan Arasy dan penanggungnya (para malaikat) ditanggung oleh Qudrah-Nya, kesemuanya itu dikuasai dalam genggaman-Nya. Sesungguhnya Dia di atas Arasy dan di atas setiap 
sesuatu kepada sempadan bintang Surayya. Sifat atas tersebut tidak menghampirkanNya kepada Arasy dan langit, bahkan tinggi darjat-Nya lebih daripada Arasy sepertimana tinggi darjat Surayya daripada Arasy. Dia hampir dengan seseorang hamba iaitu lebih hampir daripada urat lehernya dan Dia Maha Menyaksikan atas segala sesuatu. (alAsh'ari 1977: 2/21)

Pada ungkapan kedua, Imam al-Ash'ari didapati bersikap lebih terbuka dengan memberikan sedikit peranan kepada akal dalam menghilangkan kejumudan pemikiran ketika berinteraksi dengan nas-nas al-Quran dan hadis. Penggunaan dalil 'aqli menurut Imam alAsh'ari bertujuan mengukuhkan dalil naqli berasaskan hujah mantik dan bukti-bukti alam semesta sehingga membawa kepada keimanan kepada Allah s.w.t. Imam al-Ash'ari turut berpendapat bahawa kesepaduan di antara dalil naqli dan dalil 'aqli akan lebih memudahkan umat Islam memahami akidah dan menjadikan proses dakwah kepada masyarakat bukan Islam semakin bertambah menyakinkan. Namun Imam al-Ash'ari bukanlah tokoh pertama dalam kalangan Ahl al-Sunnah wa al-Jama'ah yang mengenengahkan peranan akal, kerana terdapat tokoh lain seperti Ibn Kullab (m. 240H), al-Harith al-Muhasibi (m. 243H) dan lain-lain telah membicarakan terlebih dahulu tentang kepentingan menggunakan akal dalam kehidupan beragama manusia seharian (al-Sharastani 1993: 1/105-1/106; Abdul Shukor 1994: 39; alZuhaili 2009: 1/106-1/107).

Menurut al-Zuhaili (2009: 1/106), penelitian mendapati bahawa terdapat tiga faktor utama yang menyebabkan Imam al-Ash'ari menerima akal sebagai salah satu dalil dalam persoalan akidah iaitu: Pertama, Imam al-Ash'ari pada asalnya berfahaman Muktazilah yang mengutamakan akal berbanding nas-nas al-Quran dan hadis, maka sudah tentu beliau sangat pakar dalam penggunaan dalil 'aqli. Beliau mendapati Muktazilah dan aliran-aliran lain sering menggunakan permainan akal untuk mendatangkan keraguan dan menyebarkan akidah menyeleweng kepada umat Islam. Kedua, Imam al-Ash'ari dan ulama Asha'irah di antara kumpulan yang bersungguh-sungguh dalam mempertahankan dan menghadapi golongan bidaah serta atheis. Kebanyakan golongan tersebut tidak berminat dengan penghujahan dalil naqli semata-mata, bahkan mereka lebih cenderung kepada penjelasan dalil 'aqli. Ketiga, Imam al-Ash'ari bangun menentang penyelewengan melampau Muktazilah setelah beliau kembali kepada Ahl al-Sunnah wa al-Jama'ah. Beliau terpaksa menggunakan semula pendekatan hujah akal Muktazilah, di samping mendatangkan dalil naqli sebagai mengukuhkan lagi dalil 'aqli yang digunakan terhadap Muktazilah.

Kebanyakan pendirian Imam al-Ash'ari tentang peranan dalil 'aqli ditemui dalam beberapa karya beliau seperti Risalah fi al-Istihsan al-Khawd fi 'Ilm al-Kalam dan al-Luma' fi alRad 'ala Ahl al-Zaygh wa al-Bid'a. Sebagai contoh, menerusi al-Luma' fi al-Rad 'ala Ahl al-Zaygh wa al-Bid'a, Imam al-Ash'ari tidak lagi membincangkan tentang nas-nas sifat mutashabihat berdasarkan metod Salaf secara meluas, malah beliau hanya memberikan penekanan terhadap kepincangan fahaman Mushabbihah atau Mujassimah yang memahami lafaz nas-nas sifat mutashabihat secara literal sehingga menyerupakan atau menjisimkan Allah s.w.t. dengan makhluk-Nya (al-Ash'ari 1955: 19-24). Imam al-Ash'ari lebih menfokuskan penggunaan hujah akal dalam mempertahankan al-Quran dan hadis, tidak seperti karya-karya sebelum ini yang didapati tidak memberi peranan kepada dalil 'aqli. Keadaan tersebut berbeza dengan metod yang digunakan oleh beliau sebelum ini yang tidak cenderung menjadikan Ilmu Kalam sebagai hujah pendalilan dalam perbahasan akidah (al-Ash'ari 1955: 5; al-Shayrazi 1999: 69).

Selain itu, Imam al-Ash'ari diriwayatkan telah melakukan takwilan terhadap lafaz yad (tangan) dengan maksud berkuasa dalam karya al-Luma' tersebut (al-Razi 1981: 12/46; alSuyuti t.th: 4/1364; Abu Zahrah 1996: 170). Takwilan ini dikuatkan lagi dengan pendirian sebilangan ulama Salaf seperti Ibn 'Abbas r.a. (m. 68H) yang turut mentakwilkan yad dengan maksud kekuatan dan kekuasaan Allah s.w.t. (al-Qurtubi 2006: 19/503). Hakikatnya, takwilan yang dikemukakan oleh Imam al-Ash'ari dan kebanyakan ulama Khalaf adalah bersesuaian dengan tuntutan dan keperluan zaman kini disebabkan kemunculan pelbagai aliran pemikiran, perdebatan ilmiah serta perkembangan ilmu balaghah bahasa Arab yang semakin komplikasi berbanding zaman Salaf (al-Buti 2009: 141; Mohd Farid 2008: 93-95). Namun harus ditegaskan 
bahawa takwilan Imam al-Ash'ari tersebut adalah berbeza sama sekali dengan metod takwil Muktazilah atau Mu'attilah yang bermaksud mengingkari dan menafikan sifat bagi Allah s.w.t. dengan cara mentakwilkan kepada perkara tidak selayaknya (al-Buti 2007: 137).

Penjelasan di atas menunjukkan bahawa Imam al-Ash'ari telah membentuk metodologi pendalilan tersendiri dalam persoalan akidah, iaitu tidak terlalu literal dalam memahami dalil naqli sepertimana Mushabbihah atau Mujassimah dan Hashawiyyah, tidak juga terlalu bebas menggunakan akal sepertimana Muktazilah. Malah Imam al-Ash'ari dalam hal tersebut akan mengutamakan dalil naqli daripada akal kerana al-Quran dan hadis merupakan sumber paling berwibawa dan muktamad berbanding dalil 'aqli (al-Ghazali 1994: 21; Abdul Shukor 1994: 40). Ini kerana kemampuan akal adalah terbatas untuk mengetahui perkara berkaitan hakikat zat Allah s.w.t. disebabkan Allah s.w.t. tidak menyerupai atau menyamai makhluk ciptaan-Nya. Maka itu Islam melarang umatnya daripada berfikir secara berlebih-lebihan tentang hakikat zat Allah s.w.t. kerana walaupun sepintar dan sehebat mana sekalipun seseorang itu, mereka sama sekali tidak berkemampuan untuk menyingkap keagungan dan kebesaran zat Allah s.w.t. (alHindi (5704) 1989: 3/106).

\section{Analisis Peringkat Pemikiran Imam al-Ash'ari}

Setelah Imam al-Ash'ari meninggalkan Muktazilah, beliau telah menyertai Ahl al-Sunnah wa alJama'ah dengan menulis sebuah karya untuk membantah dan membongkar kesesatan Muktazilah yang berlebih-lebihan dalam menggunakan akal berbanding al-Quran dan hadis (Ibn al-'Asakir 1347H: 39). Muktazilah telah melakukan takwilan terhadap nas-nas sifat mutashabihat kerana mereka berpandangan jika Allah s.w.t. memiliki sifat, maka telah wujud dua perkara qadim; pertamanya sifat-Nya yang qadim dan keduanya zat-Nya yang qadim. Hal ini bercanggah dengan konsep falsafah akal yang menjadi pegangan mereka iaitu kewujudan sesuatu yang qadim adalah esa dalam semua aspek (al-Hafani 2000: 817). Maka secara logiknya tindakbalas pantas Imam al-Ash'ari terhadap pendirian Muktazilah tersebut sudah tentu dengan menetapkan al-Quran dan hadis terlebih dahulu. Agak mustahil Imam al-Ash'ari akan memasukkan elemen memartabatkan akal dalam menghadapi kesesatan Muktazilah pada ketika itu memandangkan beliau baru sahaja berlepas diri daripada Muktazilah. Justeru, karya al-Ibanah 'an Usul al-Diyanah didapati paling sesuai dipadankan dengan situasi berkenaan berbanding karya-karya lain, walaupun Maqalat al-Islamiyyin wa Ikhtilaf al-Musallin turut mempertahankan metod Salaf sebagai pendekatan utama dalam pengukuhan akidah Islam. Pandangan ini berasaskan kandungan Maqalat al-Islamiyyin wa Ikhtilaf al-Musallin yang tidak menfokuskan perbincangan kesesatan Muktazilah sahaja secara terperinci dengan sepenuh emosi sebagaimana al-Ibanah 'an Usul al-Diyanah.

Manakala sebilangan penulis lagi beranggapan al-Luma' fi al-Rad 'ala Ahl al-Zaygh wa alBid'a adalah karya terawal Imam al-Ash'ari, namun berdasarkan kandungan karya tersebut sebagaimana telah dijelaskan, sukar untuk dikaitkan al-Luma' fi al-Rad 'ala Ahl al-Zaygh wa alBid'a sebagai karya terawal Imam al-Ash'ari setelah beliau meninggalkan Mu'tazilah (Haji Mahyuddin 2007: 32-39). Kemungkinan kaitan yang dapat diketengahkan dalam menyatakan al-Luma' fi al-Rad 'ala Ahl al-Zaygh wa al-Bid'a adalah karya terawal Imam al-Ash'ari berdasarkan kecenderungan beliau dalam mentakwilkan nas-nas sifat mutashabihat sebagaimana Mu'tazilah (al-Razi 1981: 12/46; Abu Zahrah 1996: 170). Namun andaian ini didapati tidak bertepatan dengan tindakan yang sepatutnya dilakukan oleh Imam al-Ash'ari setelah beliau meninggalkan Muktazilah, iaitu beliau mesti membongkar segala penyelewengan Muktazilah dalam tulisan pertamanya itu. Malah menyatakan al-Luma' fi al-Rad 'ala Ahl al-Zaygh wa al-Bid'a adalah karya kedua Imam al-Ash'ari selepas al-Ibanah 'an Usul al-Diyanah turut dilihat kurang meyakinkan dengan kandungan al-Luma' fi al-Rad 'ala Ahl al-Zaygh wa al-Bid'a yang menggunakan takwil dan dalil 'aqli secara meluas dan tersusun. Tidak mungkin Imam alAsh'ari begitu cepat menerima semula peranan akal setelah beliau mengkritik Muktazilah di atas sebab keterlaluan mereka menggunakan akal semata-mata. Manakala kenyataan Ibn al'Asakir (1347H: 39) tentang al-Luma' merupakan di antara karya terawal Imam al-Ash'ari dapat 
dipertikaikan kerana terdapat tiga buah karya Imam al-Ash'ari bermula dengan lafaz al-Luma' (Ibn al-'Asakir 1347H: 130). Malah menurut Ibn al-'Asakir (1347H: 39) lagi, karya al-Luma' dimaksudkan itu lebih dikenali sebagai Kashf al-Asrar wa Hatk al-Astar, bukan al-Luma' fi al-Rad 'ala Ahl al-Zaygh wa al-Bid'a.

Selain itu, penelitian penulis terhadap karya Risalah Ila Ahl al-Thaghr menunjukkan bahawa Imam al-Ash'ari telah menggunakan kedua-dua metod sama ada Salaf atau Khalaf dalam berinteraksi dengan nas-nas sifat mutashabihat. Menurut Imam al-Ash'ari, menjadi suatu kewajipan untuk umat Islam berkeyakinan dan beramal dengan nas-nas berbentuk muhkamat, sedangkan nas-nas mutashabihat sekadar perlu diiktiraf dan diimani sesuai dengan sifat-sifat kesempurnaan-Nya sahaja. Walaupun Imam al-Ash'ari masih berpegang dengan metod Salaf, tetapi beliau turut melakukan takwilan terhadap lafaz reda Allah s.w.t. dengan maksud kehendak-Nya terhadap nikmat, serta lafaz marah Allah s.w.t. dengan maksud kehendak-Nya terhadap azab (al-Ash'ari 2002: 225; 231-232; 293). Dalam riwayat lain, Imam al-Ash'ari dilaporkan melakukan takwilan terhadap lafaz reda Allah s.w.t. dengan maksud kehendak-Nya dalam memuliakan orang-orang beriman, serta lafaz marah Allah s.w.t. dengan maksud kehendak-Nya dalam mengazabkan orang-orang kafir (al-Bayhaqi 2005: 493).

Maka karya Risalah ila Ahl al-Thaghr mungkin dapat dikatakan sebagai suatu tempoh masa peralihan pemikiran Imam al-Ash'ari daripada menerima dalil naqli sahaja kepada turut menerima dalil 'aqli juga. Ini bermaksud Imam al-Ash'ari tidak bersikap tergesa-gesa menerima pendalilan akal secara konsisten sebagaimana digambarkan oleh Risalah fi al-Istihsan al-Khawd fi 'Ilm al-Kalam dan al-Luma' fi al-Rad 'ala Ahl al-Zaygh wa al-Bid'a. Kebarangkalian lain, Risalah Ila Ahl al-Thaghr mungkin juga adalah karya terakhir Imam al-Ash'ari kerana terdapat unsurunsur gabungan di antara pendekatan Salaf dan Khalaf sebagaimana pandangan Fawqiyah Husin Mahmud (1977: 1/91). Jika andaian Risalah Ila Ahl al-Thaghr adalah karya terakhir Imam al-Ash'ari dipersetujui, maka ia bertepatan dengan kaedah ulama Asha'irah yang menyatakan bahawa metod tafwid Salaf adalah lebih selamat, manakala metod takwil Khalaf adalah lebih bijaksana (al-Bayjuri 2001: 103-104). Berasaskan kaedah tersebut, kedua-dua metod iaitu tafwid dan takwil diterima pakai oleh Asha'irah sehingga kini kerana kedua-duanya pernah diketengahkan oleh Salaf dan Imam al-Ash'ari sendiri (Muhammad Rashidi \& Syed Hadzrullathfi 2012: 82-83).

Walau bagaimanapun, penulis lebih cenderung menyatakan bahawa al-Luma' fi al-Rad 'ala Ahl al-Zaygh wa al-Bid'a atau Risalah fi al-Istihsan al-Khawd fi 'Ilm al-Kalam adalah karya terakhir Imam al-Ash'ari disebabkan beliau tidak lagi membincangkan tentang tafwid Salaf, malah beliau didapati memberikan peranan kepada akal untuk menguatkan al-Quran dan hadis. Proses pemikiran ini bersesuaian dengan perkembangan seorang tokoh seperti Imam al-Ash'ari dalam membentuk kerangka metodologi pendalilan tersendiri, iaitu menggabungkan beberapa madrasah pemikiran bagi menolak aliran-aliran bidaah (al-Ash'ari 1995: 47-48; 1955: 5). Bahkan kebanyakan ulama Asha'irah sehingga kini menggunapakai metodologi tersebut dalam membahaskan persoalan akidah, membuktikan bahawa wujudnya keutuhan dan kesinambungan daripada pemikiran Imam al-Ash'ari sendiri sama ada melalui karya-karya ini atau disebarkan oleh murid-murid serta para pengikut beliau. Maka rumusan tentang peringkat kedua pemikiran Imam al-Ash'ari, iaitu ketika beliau berada dalam Ahl al-Sunnah wa al-Jama'ah, berdasarkan penelitian terhadap beberapa karya beliau sebagaimana dijelaskan, penulis berpandangan bahawa: Peringkat permulaan: al-Ibanah 'an Usul al-Diyanah dan Maqalat alIslamiyyin wa Ikhtilaf al-Musallin; Peringkat pertengahan: Risalah ila Ahl al-Thaghr, dan; Peringkat akhir: Risalah fi al-Istihsan al-Khawd fi 'Ilm al-Kalam dan Al-Luma' fi al-Rad 'ala Ahl alZaygh wa al-Bid'a.

Namun sebilangan penulis bukan dalam kalangan Asha'irah yang berpendapat al-Ibanah 'an Usul al-Diyanah merupakan karya terakhir Imam al-Ash'ari, mendakwa bahawa beliau telah bertaubat daripada berpegang dengan metod takwil Khalaf dan kembali kepada metod tafwid Salaf ketika berinteraksi dengan nas-nas sifat mutashabihat. Mereka menyamakan takwil Asha'irah dengan sebahagian daripada takwil Mu'tazilah yang bermaksud menafikan sifat-sifat khabariyyah Allah s.w.t. (al-Ansari t.th.: 88-90). Walau bagaimanapun, penelitian mendapati 
bahawa kisah taubat Imam al-Ash'ari tersebut tidak pernah ditemui dalam karya-karya beliau atau karya-karya ulama Asha'irah, malah kisah taubat Imam al-Ash'ari daripada Muktazilah sahaja yang dilaporkan oleh para sejarawan silam sebagaimana dijelaskan di atas (Ibn al-'Asakir 1347H: 39). Bahkan ulama Asha'irah yang menyatakan al-Ibanah 'an Usul al-Diyanah merupakan karya terakhir Imam al-Ash'ari, mereka tidak pernah mengemukakan kisah taubat tersebut dalam tulisan mereka (Ibn al-'Imad 1989 4/131; al-Buti 2008: 108). Ini bermaksud Imam al-Ash'ari tidak pernah menarik semula metodologi pendalilan beliau berdasarkan dalil naqli dan dalil 'aqli, maka metodologi tersebut terus dipraktikkan oleh umat Islam sehingga kini.

Sebagi kesimpulan, Asha'irah yang diasaskan oleh Imam al-Ash'ari merupakan sebuah aliran yang mempunyai pengikut teramai dalam Ahl al-Sunnah wa al-Jama'ah. Imam al-Ash'ari bertindak meninggalkan Muktazilah setelah beliau mendapati terdapat kepincangan dalam metodologi pendalilan Mukazilah yang berlebih-lebihan dalam mengutamakan logik akal berbanding nas-nas al-Quran dan hadis. Hal ini menunjukkan bahawa Imam al-Ash'ari hanya melalui dua peringkat pemikiran sahaja iaitu bersama Muktazilah sebelum berusia 37 atau 40 tahun dan seterusnya bersama Ahl al-Sunnah wa al-Jama'ah sehingga beliau meninggal dunia. Setelah bertaubat, Imam al-Ash'ari mempertahankan akidah Ahl al-Sunnah wa al-Jama'ah dengan menggunakan pendekatan Imam Ahmad bin Hanbal dan Ibn Kullab melalui karyanya alIbanah 'an Usul al-Diyanah. Karya ini dihasilkan sebagai tindakbalas awal beliau terhadap kesesatan Muktazilah terutamanya dalam isu kemakhlukan al-Quran dan penafian sifat khabariyyah Allah s.w.t. Pendirian sama turut dilihat dalam karyanya Maqalat al-Islamiyyin wa Ikhtilaf al-Musallin terutamanya berkaitan penggunaan metod tafwid Salaf ketika berinteraksi dengan nas-nas sifat mutashabihat. Namun Imam al-Ash'ari didapati telah membina kerangka asas pemikiran tersendiri melalui karyanya Risalah fi al-Istihsan al-Khawd fi 'Ilm al-Kalam dan al-Luma' fi al-Rad 'ala Ahl al-Zaygh wa al-Bid'a dengan memanfaatkan peranan akal bagi menguatkan al-Quran dan hadis. Pendekatan tersebut diketengahkan oleh beliau untuk mematahkan hujah aliran bidaah seperti Muktazilah yang terlalu bebas menggunakan akal dan mujassimah atau mushabbihah yang terlalu literal memahami wahyu.

Selain itu, tidak ditemui sebarang riwayat menunjukkan bahawa Imam al-Ash'ari pernah bertaubat daripada pegangan tersebut, menyebabkan ulama Asha'irah menetapkan pendalilan dalam persoalan akidah merangkumi dalil naqli dan dalil 'aqli. Sedangkan perselisihan tentang peringkat pemikiran Imam al-Ash'ari sama ada beliau cenderung kepada metod Salaf atau Khalaf terhadap nas-nas sifat mutashabihat hanyalah berlegar dalam metodologi Ahl al-Sunnah wa al-Jama'ah sahaja, ia bukan di antara Ahl al-Sunnah wa al-Jama'ah dengan aliran bidaah lain. Hakikat tersebut membuktikan bahawa Imam al-Ash'ari hanya melalui dua peringkat pemikiran sahaja, iaitu Muktazilah pada awalnya dan Ahl al-Sunnah wa al-Jama'ah pada akhirnya. Maka dakwaan yang menyatakan bahawa Imam al-Ash'ari menolak pendekatan takwil Khalaf pada penghujung usianya adalah suatu pandangan yang kurang bertepatan dengan fakta-fakta ilmiah. Malah Imam al-Ash'ari menggunakan kedua-dua metod Salaf dan Khalaf sehingga beliau meninggal dunia. Pendekatan tersebut terus dipraktikkan oleh majoriti umat Islam sehingga sampai generasi hari ini.

\section{References}

Abdul Shukor Husin. 1994. Asyaari dan manhajnya. Dlm. Ibrahim Abu Bakar. Spektrum Falsafah Islam. Kuala Lumpur: Dewan Bahasa dan Pustaka.

Abdul Shukor Husin. 1998. Ahli Sunah Waljamaah: pemahaman semula. Bangi: Penerbit Universiti Kebangsaan Malaysia.

Abu Zahrah, Muhammad. 1996. Tarikh al-madhahib al-Islamiyyah. Cairo: Dar al-Fikr al-'Arabi.

Ahmad Mahmud Subhi. 1985. Fi 'Ilm al-Kalam: Al-Asha'irah. Beirut: Dar al-Nahdah al-'Arabiyyah. al-'Amraji, Ahmad Shauqi Ibrahim. 2000. Al-Mu'tazilah fi Baghdad wa atharuhum fi al-hayat alfikriyyah wa al-siyasiyyah. Cairo: Maktabah al-Madbuli.

al-'Asqalani, Ahmad bin 'Ali bin Hajar. 2001. Fath al-bari. 'Abd al-Qadir Syaibah al-Hamad. (Tahqiq). Riyadh: Maktabah al-Malik. 
al-'Asqalani, Ahmad bin 'Ali bin Hajar. 2002. Lisan al-mizan. 'Abd al-Fatah Abu Ghudah. (Tahqiq). Beirut: Dar al-Bashair al-Islamiyyah.

al-Ansari, 'Abd al-Latif Hamad bin Muhammad. t.th. Muqaddimah 'ala kitab al-Ibanah 'an usul aldiyanah. dlm. Rasa'il fi al-'aqidah. t.tp. Maktabah al-Furqan.

al-Ash'ari, Abi al-Hasan 'Ali bin Isma'il. 1955. Al-Luma' fi al-rad 'ala ahl al-zaygh wa al-bid'a. Hamudah Gharabah (Tahqiq). Egypt: Matbu'ah Misriyyah.

al-Ash'ari, Abi al-Hasan 'Ali bin Isma'il. 1977. Al-Ibanah 'an usul al-diyanah. Fawqiyah Husin Mahmud. (Tahqiq). Egypt: Dar al-Ansar.

al-Ash'ari, Abi al-Hasan 'Ali bin Isma'il. 1990. Maqalat al-Islamiyyin wa ikhtilaf al-musallin. Muhammad Muhy al-Din 'Abd al-Hamid. (Tahqiq). Cairo: Maktabah al-Nahdah alMisriyyah.

al-Ash'ari, Abi al-Hasan 'Ali bin Isma'il. 1995. Risalah fi al-istihsan al-khawd fi 'Ilm al-Kalam. Muhammad al-Waly al-Ash'ari al-Qadiri al-Rifa'i. (Tahqiq). Beirut: Dar al-Mashari'.

al-Ash'ari, Abi al-Hasan 'Ali bin Isma'il. 2002. Risalah ila ahl al-thaghr. 'Abd Allah Shakir Muhammad al-Junaidy. (Tahqiq). Madinah Munawwarah: Maktabah al-'Ulum wa alHikam.

al-Asnawi, 'Abd al-Rahim Jamal al-Din. 1987. Tabaqat al-Shafi'iyyah. Beirut: Dar al-Kitab al'Ilmiyyah.

al-Bayhaqi, Abi Bakar bin al-Hassain bin 'Ali. 2005. Al-Asma' wa al-sifat. 'Abd Allah bin 'Amir. (Tahqiq). Cairo: Dar al-Hadith.

al-Bayjuri, Ibrahim bin Muhammad bin Ahmad. 2001. Tuhfah al-murid. Beirut: Dar al-Kitab al'Ilmiyyah.

al-Buti, Muhammad Sa'id Ramadan. 2007. Al-Salafiyyah: marhalah zamaniyyah mubarakah la madhhab Islami. Damascus: Dar al-Fikr.

al-Buti, Muhammad Sa'id Ramadan. 2008. Al-Madhahib al-tawhidiyyah wa al-falsafat almu'asarah. Damascus: Dar al-Fikr.

al-Buti, Muhammad Sa'id Ramadan. 2009. Kubra al-yaqiniyyat al-kawniyyat. Damascus: Dar alFikr.

al-Dzahabi, Shams al-Din Muhammad bin Ahmad bin 'Uthman. 1996. Siyar a'lam al-nubala. Shu'aib al-Arnauk. (Tahqiq). Beirut: Muassasah al-Risalah.

al-Ghari, Zamihan Mat Zin. 2001. Salafiyyah Wahabiyyah: satu penilaian. Selangor: Tera Jaya Enterprise.

al-Ghazali, Abu Hamid Muhammad bin Muhammad. 1994. Al-Iqtisad fi al-i'tiqad. Muwaffaq Fauzi al-Jabr. (Tahqiq). Damascus: al-Hikmah.

al-Hafani, 'Abd al-Mun'im. 2000. Al-Mu'jam al-shamil li mustalahat al-falsafah. Cairo: Maktabah al-Madbuli.

al-Hakim, Muhammad bin 'Abd Allah bin 'Abd Allah. 1990. Al-Mustadrak 'ala al-Sahihain. Mustafa 'Abd al-Qadir 'Ata. (Tahqiq). Beirut: Dar al-Kitab al-'Ilmiyyah.

al-Hindi, 'Ali al-Din Muttaqi bin Hisham al-Din. 1989. Kanz al-'ummal fi sunan al-aqwal wa alaf'al. Beirut: Muassasah al-Risalah.

al-Kawthari, Muhammad Zahid. 2009. Al-'Aqidah wa Ilm al-Kalam. Beirut: Dar al-Kitab al'Ilmiyyah.

al-Mahdali, al-Sayyid Muhammad 'Aqil bin 'Ali. 1993. Ahl al-Sunnah wa al-Jama'ah: madkhal wa dirasah. Cairo: Dar al-Hadith.

al-Mahmud, 'Abd al-Rahman bin Saleh bin Saleh. 1995. Mawqif Ibn Taymiyyah min al-Asha'irah. Riyad: Maktabah al-Rushd.

al-Qaradawi, Yusuf. 2012. La Fatwa li Shaltut bi al-tacbud 'ala al-Ja'fary, http://www.qaradawi.net/news/537.html [10 November 2012].

al-Qurtubi, Abi 'Abd Allah Muhammad bin Ahmad bin Abi Bakar. 2006. Al-Jami' al-ahkam alQuran. Tahqiq: 'Abd Allah bin 'Abd al-Muhsin al-Tarki. Beirut: Muassasah al-Risalah.

al-Razi, Fakh al-Din Muhammad bin 'Umar. 1981. Al-Tafsir al-kabir. Beirut: Dar al-Fikr.

al-Sharastani, Abi al-Fath Muhammad 'Abd al-Karim bin Abi Bakar. 1993. Al-Milal wa nihal. Amir 'Ali Mahna \& 'Ali Hasan Fa'ur. (Tahqiq). Beirut: Dar al-Ma'rifah. 
al-Shayrazi, Abi Ishaq. 1999. Al-Isharah ila mazhab ahl al-haq. Muhammad al-Sayyid al-Jalayand. (Tahqiq).Cairo: Al-Majlis al-A'la Lilshu'un al-Islamiyyah.

al-Subki, Taqi al-Din Abi Nasr 'Abd al-Wahab bin 'Ali bin 'Abd al-Kafi. t.th. Tabaqat al-Shafi'iyyah al-kubra. t.tp: Dar Ihya' al-Kitab al-'Arabiyyah.

al-Suyuti, Jalal al-Din 'Abd al-Rahman. t.th. Itqan fi 'Ulum al-Quran. Markaz al-Dirasat alQuraniyyah. (Tahqiq). Madinah Munawwarah: al-Mamlakah al-'Arabiyyah al-Sa'udiyyah.

al-Zabidi, al-Sayyid Muhammad bin Muhammad al-Husaini. 1989. It'haf al-sadah al-muttaqin. Beirut: Dar al-Kitab al-'Ilmiyyah.

al-Zuhaili, Muhammad. 2009. Mausu'ah qadaya Islamiyyah mu'asarah. Damascus: Dar alMaktabi.

Fawqiyah Husin Mahmud. 1977. Muqaddimah al-Ibanah 'an usul al-diyanah. Egypt: Dar al-Ansar.

Haji Muhyuddin Haji Hashim. 2007. Imam Asy'ari pengasas mazhab Asya'irah pembuka jalan penyelesaian. Mesir: Persekutuan Melayu Republik Arab Mesir.

Hamda al-Sinan \& Fauzi al-Anjari. 2006. Ahl al-Sunnah al-Asha'irah. Kuwait: Dar al-Diya'.

Hamudah Gharabah. 1955. Muqaddimah al-Luma' fi al-rad 'ala ahl al-zaygh wa al-bid'a. Egypt: Matbu'ah Misriyyah.

Ibn al-'Asakir, Abi al-Qasim 'Ali bin al-Hasan bin Hibah Allah. 1347H. Tabyin kadhib al-muftari fima nusiba ila al-Imam Abi al-Hasan al-Ash'ari. Damascus: t.pt.

Ibn al-'Imad, Shihab al-Din Abi al-Falah 'Abd al-Hay bin Ahmad bin Muhammad al-Hanbali. 1989. Shadharat al-dhihab fi akhbar min dhahab. 'Abd al-Qadir al-Arnauk. (Tahqiq). Damascus: Dar Ibn Kathir.

Ibn Kathir, Abi al-Fida' Isma'il bin 'Umar bin Kathir. 1998. Al-Bidayah wa al-nihayah. 'Abd Allah bin 'Abd al-Muhsin al-Tarki. (Tahqiq). Giza: Dar Hijr.

Ibn Kathir, Abi al-Fida' Ismacil bin 'Umar bin Kathir. 1999. Tafsir al-Quran al-cAzim. Sami bin Muhammad al-Salamah. (Tahqiq).Riyad: Dar Thaibah.

Ibn Khaldun, 'Abd al-Rahman bin Muhammad. t.th. Muqaddimah Ibn Khaldun. Tahqiq: 'Ali 'Abd al-Wahid Wafi. Cairo: Dar Nahdah Misr.

Ibn Khalikan, Abi al-'Abbas Shams al-Din Ahmad bin Muhammad bin Abi Bakar. t.th. Wafayat ala'yan wa anba' abna' al-zaman. Beirut: Dar al-Thaqafah.

Mohd Farid Mohd Shahran. 2008. Isu-Isu dalam pemikiran Islam. Kuala Lumpur: Angkatan Belia Islam Malaysia.

Muhammad Rashidi Wahab \& Syed Hadzrullathfi Syed Omar. 2012. Takwilan nas-Nas sifat mutashabihat dalam kalangan Salaf. The Global Journal al-Thaqafah. Perak: Kolej Islam Darul Ridzuan.

Muslim, Abi al-Hussain Muslim bin al-Hajjaj. 2008. Sahih Muslim. Al-Qahirah: Dar Ibn Hazm.

The Royal Islamic Strategic Studies Centre. 2010. The 500 most influential Muslims in the world 2010. Washington D.C: Georgetown University. 